Article

\title{
Institutionalizing Sustainability across the Federal Government
}

\section{Kenneth W. Abbott ${ }^{1,2, *}$ and Gary E. Marchant ${ }^{1}$}

1 Center for Law, Science and Innovation, Sandra Day O'Connor College of Law, Arizona State University, P.O. Box 877906, Tempe, AZ 85287-7906, USA; E-Mail: gary.marchant@asu.edu

2 School of Politics and Global Studies, Arizona State University, P.O. Box 877906, Tempe, AZ 85287-7906, USA

* Author to whom correspondence should be addressed; E-Mail: ken.abbott@ asu.edu; Tel.: +1-480-965-5917; Fax: +1-480-727-6973.

Received: 16 April 2010; in revised form: 13 June 2010 / Accepted: 22 June 2010 /

Published: 2 July 2010

\begin{abstract}
A notable aspect of sustainability is its holistic and cross-cutting nature-it cannot be achieved by any single rule, statute or agency. Instead, sustainability must be institutionalized across the legal system and government as a whole. In this paper, we propose and examine five mechanisms for institutionalizing sustainability across the federal legal system: (1) an Executive Order on sustainability; (2) a sustainability impact assessment process; (3) a non-partisan Congressional Joint Committee on Sustainability; (4) a federal Sustainability Commission; and (5) a Sustainability Law Reform Commission. Each is modeled on an existing institution in the United States or another jurisdiction. We discuss and compare the advantages and disadvantages of each mechanism, and discuss how the mechanisms might best be used, singly or in combination, to institutionalize sustainability across the federal government.
\end{abstract}

Keywords: sustainability; sustainable development; institutional analysis; executive order; environmental impact assessment; government commissions; law reform; governance

\section{Introduction}

The core attribute of sustainability - and its major challenge - is the breadth of the concept. Sustainability is holistic: it cuts across multiple areas of knowledge, forms and areas of law, and institutional mandates. As the Bruntland Commission made clear in 1987, environmental, economic 
and social change each "represents a formidable challenge in its own right, but the fundamental challenge stems from their systemic character.... Separate policies and institutions can no longer cope effectively with these interlocked issues" ([1], Chapter 12, § 9).

In the United States, much as in 1987, however, "the integrated and interdependent nature of the new challenges and issues contrasts sharply with the nature of the institutions that exist today. These institutions tend to be independent, fragmented, and working to relatively narrow mandates ..." ([1], Chapter $12, \S 10)$ Because sustainability issues arise under virtually every federal agency, statute, program, policy and action, it will be impossible to respond in the same way our legal system has addressed other emerging issues: by enacting or revising a single statute and granting authority to a single agency. Instead, sustainability must be institutionalized across the legal system and government as a whole [2].

In this paper, we examine five potential mechanisms for institutionalizing sustainability across the federal legal system, particularly for legislative and regulatory law and executive branch policies. To help ensure that the mechanisms we consider are viable, we model each of them on an institution that is currently in operation, in the United States or some other jurisdiction. In selecting these mechanisms, we have focused on identifying institutional innovations that would (a) inject sustainability more directly into the processes by which laws, regulations and policies are adopted and reviewed, and (b) enhance the responsibilities of major units of government to further sustainability.

The five mechanisms are:

(1) an Executive Order requiring federal agencies to consider the sustainability implications of all regulatory decisions and authorizing the Office of Management and Budget (OMB) to review agency proposals, modeled on President Obama's October 2009 order on environmental performance;

(2) a sustainability impact assessment process requiring consideration of sustainability in all federal agency actions, modeled on the existing environmental impact assessment process under the National Environmental Policy Act (NEPA), or perhaps moving towards the broader strategic environmental assessment model adopted by nations such as Canada;

(3) a non-partisan Congressional Joint Committee on Sustainability, modeled on the existing Joint Committee on Taxation and Joint Economic Committee;

(4) a federal Sustainability Commission, based on the UK Sustainable Development Commission; and

(5) a Sustainability Law Reform Commission, based on law reform commissions in Britain, the Commonwealth and some US states.

We assess the advantages and disadvantages of each mechanism and consider how they might best be adapted to institutionalize sustainability across the federal government.

To focus on these concrete institutional innovations, we largely set aside other important, closely related issues. First, we do not grapple with the precise meaning of "sustainability". Consistent with other articles in this special issue [3] and with widely accepted usage [4], we treat "sustainability" as synonymous with "sustainable development". Sustainability therefore includes not only keeping human development within ecological limits, but also ensuring that a wide range of social arrangements are (intra-generationally) equitable. The Bruntland Commission famously emphasized the synergies among these and other elements of sustainable development; in practice, however, policy-makers pursuing sustainability frequently encounter contradictions among them. Institutional 
mechanisms like those discussed here are designed to ensure that even highly specialized organs of government come to grips with the intellectual and political challenges sustainability poses.

Second, we do not consider potential substantive statutes, regulations or policies related to sustainability. To achieve sustainability, of course, both substantive and institutional innovations will ultimately be needed, and both should be integrated into a comprehensive national sustainability strategy, a point to which we return in the Conclusion. For the present, though, we focus on institutional mechanisms that could become components of a more comprehensive strategy.

Third, we address only a subset of the institutional issues involved in achieving "governance for sustainability". We focus exclusively on the federal legal and political system in the United States; we do not address global, sub-national, private or other forms of governance for sustainability.

\section{Five Institutional Mechanisms for Sustainability}

\subsection{Executive Order on Sustainability}

An Executive Order (E.O.) is a directive from the head of government (the President at the federal level) that seeks to manage the administration of federal agencies [5]. A broad E.O. on sustainability could institutionalize sustainability across the federal bureaucracy, potentially transforming how government agencies make decisions and conduct their business. It could require agencies to adopt sustainability strategies, consider the sustainability implications of decisions, establish specialized units and procedures, and take concrete actions. As an internal management tool of the Executive branch, an E.O. need not be approved by Congress, making it fast and flexible.

An important precedent is President Clinton's 1994 E.O. 12898 on environmental justice [6]. This E.O. was designed to incorporate environmental justice considerations into the regulatory decisions and other actions of federal agencies, by requiring agencies to "identify and address ... disproportionately high and adverse human health or environmental effects of its programs, policies, and activities on minority populations and low-income populations" ([6], § 1-101). More concretely, the E.O. requires each agency to develop an environmental justice strategy that lists the "programs, policies, planning and public participation processes, enforcement, and/or rulemakings related to human health or the environment that should be revised" in response to environmental justice concerns ([6], § 1-103). The E.O. is particularly important for its incorporation of social equity along with environmental issues, consistent with the elements of sustainability.

This E.O. has had some modest effects, especially by leading certain agencies to create environmental justice review procedures and by inserting environmental justice as a required element of environmental impact assessments. Nevertheless, the environmental justice E.O., like many others, has a significant structural weakness: E.O.'s are generally not enforceable in court, as they create no new legal rights; the lack of external enforcement has resulted in widespread agency non-compliance [7,8]. An additional problem with this particular E.O. was the lack of clear, operationalized definitions and standards, which made it difficult for even a sincere agency to implement environmental justice ([7], pp. 390-391). The same problem could arise with a sustainability E.O., given the complexity and sometimes conflicting elements of the concept of sustainability. Still, a sustainability E.O. could improve federal policy-making even if it merely caused 
specialized agencies to identify and consider the environmental and social consequences of their actions.

In October 2009, President Obama issued E.O. 13514, titled "Federal Leadership in Environmental, Energy, and Economic Performance" [9]; this is commonly referred to as an E.O. on sustainability, although its focus is almost wholly on environmental sustainability. E.O. 13514 includes some important first steps in implementing sustainability across the government. Its specific mandates require federal agencies to reduce greenhouse gas emissions, improve water efficiency, and implement pollution prevention and waste reduction programs ([9], § 2). It also imposes requirements for new federal buildings to promote environmentally-friendly design, as well as procurement rules for federal agencies that incorporate sustainability goals ([9], § 10,13). Finally, E.O. 13514 creates a steering committee on sustainability across federal agencies ([9], § 3). Although it is too early to evaluate fully the impact of E.O. 13514, it clearly implements a number of concrete steps toward more sustainable government operations.

Yet President Obama's E.O. 13514 could be strengthened in significant ways. For one thing, the E.O. does not currently require agencies to expressly address sustainability principles in their regulatory, policy and programmatic decisions. To be sure, such a requirement might be controversial, as it would skirt the legislative power to determine the regulatory criteria agencies must apply. [10] However, previous E.O.'s addressing societal concerns such as environmental justice, children's health and safety, and federalism have required agencies to consider the impacts of regulatory decisions in those areas. For example, President Clinton's E.O. on environmental justice required federal agencies to "identify and address" environmental justice problems ([6], § 1-103). An enhanced sustainability E.O. could likewise require agencies to "identify and address" any potential adverse sustainability impacts resulting from their decisions. Potential conflicts with existing statutory provisions could be ameliorated by including with these requirements the qualifier, "to the full extent permitted by law".

In addition, an E.O could require federal agencies to develop strategies to improve their sustainability performance. There are important precedents for such a mandate. For example, President Clinton's order required agencies to develop environmental justice strategies ([6], § 1-103), the government of the United Kingdom requires agencies to adopt Sustainable Development Action Plans [11], and the State of New York requires each state agency to develop and implement a "Sustainability and Environmental Stewardship Program” [12]. Beyond their immediate impact on decision-making, the mutually-supporting requirements to identify sustainability impacts and to develop strategies to improve sustainability outcomes would likely have broader expressive and subjective effects, e.g., by improving agencies' sensitivity to and internalization of sustainability principles, just as the environmental justice E.O. led to increased consideration of environmental justice in environmental impact assessments. In fact, a strengthened E.O. on sustainability would complement the existing environmental justice E.O. in that both extend beyond traditional environmental protection to consider social and ethical impacts; they would, however, need to be coordinated to minimize any overlaps or inconsistencies.

Executive Orders have several beneficial attributes as mechanisms for introducing sustainability. Most importantly, they can be adopted quickly and efficiently, since a single individual (the President) can simply issue the necessary instrument without any lengthy formal process [13]. This allows the President to quickly adopt or revise an E.O. in response to rapidly moving events and trends, and 
avoids the partisan wrangling and gridlock that affects Congress. Moreover, because an E.O. cannot be enforced in court, it does not risk being tied up in lengthy litigation. Finally, since an E.O. addresses agencies already under the direct oversight of the President, those agencies should be sympathetic, or at least prepared to respond, to the President's directions. Finally, beyond its direct effects on federal agencies, an E.O. also serves an expressive function, both by demonstrating government leadership and by sending a message about national goals and priorities that often reverberates across the entire economy [13].

Yet some of these very strengths also constitute the Achilles' heel of Executive Orders. One significant limitation stems from the status of E.O.'s as internal management tools for the Executive branch: to the extent an E.O. seeks to go beyond that role to set policy, it may be susceptible to Congressional, judicial or other challenge, limiting its impact [5,10]. A second limitation stems from E.O. unenforceability. The record of E.O.'s such as President Clinton's environmental justice order suggests that agency compliance with both the terms and the spirit of an E.O. can be spotty at best. Finally, the ease with which an E.O. can be adopted also means that it can be easily rescinded, so an E.O. does not provide the same long-term stability and certainty as a statute [13].

\subsection{Sustainability Impact Assessments}

Environmental impact assessment (EIA) policies require government agencies to consider the positive and negative environmental effects of proposed agency projects, typically through a formal process which results in a written impact statement. EIAs have already been mandated for federal government actions that may significantly impact the human environment under NEPA, the first major statute of the modern environmental regulatory era. This innovative requirement has now been replicated by over 100 jurisdictions, including several U.S. states and many nations [14]. Nonetheless, the NEPA requirements could be modified to promote sustainability more effectively by expanding their substantive criteria, strengthening their procedures, and extending the EIA process to broader categories of agency policies and programs-moving toward a new concept of sustainability impact assessment.

NEPA was in important ways the first sustainability statute. It directed federal agencies to evaluate ex ante the potential impacts of their actions on the quality of the human environment and to consider less damaging alternatives. As expressed in NEPA, "it is the continuing responsibility of the Federal Government to use all practicable means, consistent with other essential considerations of national policy, to improve and coordinate Federal plans, functions, programs, and resources to the end that the Nation may-(1) fulfill the responsibilities of each generation as trustee of the environment for succeeding generations; (2) assure for all Americans safe, healthful, productive, and aesthetically and culturally pleasing surroundings; (3) attain the widest range of beneficial uses of the environment without degradation, risk to health or safety, or other undesirable and unintended consequences; (4) preserve important historic, cultural, and natural aspects of our national heritage, and maintain, wherever possible, an environment which supports diversity, and variety of individual choice; (5) achieve a balance between population and resource use which will permit high standards of living and a wide sharing of life's amenities; and (6) enhance the quality of renewable resources and 
approach the maximum attainable recycling of depletable resources" [15]. This may be the strongest statement of sustainability principles in federal law.

Although the substantive requirements of NEPA have been diminished by successive Supreme Court decisions [16], its procedural requirements remain a powerful tool for forcing government agencies to consider the impacts of their actions. Specifically, NEPA requires federal agencies to produce environmental impact statements for "major Federal actions significantly affecting the quality of the human environment" ([15], §102). While some critics argue that, as currently applied, the EIA requirement does not adequately further the environmental objectives it was intended to promote [17], this procedure still provides a natural vehicle for institutionalizing stronger consideration of sustainability across the federal government.

One way in which EIAs could be extended to better promote sustainability would be to require consideration of additional substantive criteria. Perhaps most important, NEPA could be amended to require express consideration of the inter-generational impacts of proposed actions; such impacts are, of course, at the core of the concept of sustainability. Alternatively, it may be possible for the White House Council on Environmental Quality (CEQ) to amend or reinterpret its regulations under NEPA to incorporate an inter-generational component, perhaps by expanding Section 102(2)(C)(iv) of NEPA, which already requires consideration of "the relationship between local short-term uses of man's environment and the maintenance and enhancement of long-term productivity" [18]. More concretely, while NEPA currently requires some consideration of cumulative impacts, this requirement could be significantly strengthened given the critical importance of cumulative effects in determining sustainability.

NEPA could also be amended to require more effective EIA procedures. In particular, sustainability norms favor a shift from the current one-time, ex ante analysis of impacts to a more ongoing, adaptive approach [19]. EIAs have for the most part been static rather than dynamic: they do not monitor the impacts of projects over time to assess either the accuracy of the original assessments or new issues that may arise during the course of the projects. An approach more compatible with long-term sustainability would require an ongoing, dynamic EIA that would identify and consider new or under-estimated impacts and respond in a timely fashion.

An even more dramatic enhancement would be to expand EIA beyond individual agency projects to include policies, programs and conceptual activities, a process referred to as "strategic environmental assessment" (SEA) [20]. The initial impetus for this focus on higher-level decisions was a 1987 World Bank paper which argued that "environmental issues must be addressed as part of overall economic policy rather than project-by-project", as is the case for traditional EIAs [21]. Now adopted in many nations [22], SEA is often expressly linked to promoting sustainability [23]. SEA might thus be a better vehicle than traditional project-based EIA to incorporate intra- as well as inter-generational impacts, although that would likely require a statutory enactment. (One benefit of enhancing the current EIA requirement is that it may be possible to achieve administratively without statutory amendment.)

As implemented in other nations, SEA requires a concise analysis of the impacts of proposed policies and programs, as well as the major alternatives, undertaken at a higher level and an earlier stage in policy development than EIAs on specific projects ([23], p. 4). For example, in Canada a "Cabinet Directive on the Environmental Assessment of Policy, Plan and Program Proposals" requires 
explicit consideration of the environmental and socioeconomic sustainability impacts of all policy and program proposals submitted to the Cabinet for consideration [24]. The Directive states that "[b]y addressing potential environmental considerations of policy, plan and program proposals, departments and agencies will be better able to .... [i]mplement sustainable development strategies" ([24], p. 3). However, a recent review of the implementation of this Directive found wide variation in methodology and outcomes, and mixed success overall. These problems can be attributed mainly to the diversity of situations in which SEA is required, the lack of objective criteria and insufficiently transparent analyses [20].

The likely limitations of any attempt to institutionalize sustainability via an enhanced EIA mechanism are based on the general limitations of EIA itself. Numerous criticisms have been leveled at EIA, including the amount of time and resources needed to complete an assessment, the low quality of information and analysis often included, and the "ritualization" of the process within agencies, stimulated by a desire to make litigation-proof decisions [19]. As one commentator summarized the problems, EIA "places extreme demands on agency resources, often generates little useful information, and produces a work product too late in the decision-making cycle to influence the agency's course of action" ([19], p. 907).

Strengthening the sustainability focus of EIA runs the risk of exacerbating some of these problems. Adding additional substantive criteria would likely extend both the duration of the EIA process and the length of the assessment documents, perhaps further reducing their utility for decision-makers. Similarly, additional requirements may stretch over-extended agencies, resulting in further deterioration of information quality. The difficulty of operationalizing sustainability may complicate the process, resulting in greater controversy, variability and litigation. Finally, just as with the current EIA process, while a requirement to evaluate sustainability impacts may help inform policymakers and the public of sustainability concerns, it will not guarantee that those impacts are actually addressed. Indeed, the empirical record of SEA, which explicitly incorporates sustainability considerations, is mixed at best [23].

\subsection{A Joint Congressional Committee on Sustainability}

A Joint Committee on Sustainability, drawn from both houses of Congress, would focus Congressional attention on sustainability issues that cut across many areas of law-and thus across the jurisdiction of multiple committees - elevating those issues in the Congressional structure to a degree of prominence currently reserved for economic matters. More concretely, a joint committee would provide continuity throughout the legislative process, facilitating management of complex sustainability legislation. The committee could be given a non-partisan expert staff, which would provide valuable input into the drafting and evaluation of legislative proposals. Finally, the committee would promote the accumulation of knowledge among members and staff on the sustainability implications of various bodies of law, and diffuse that knowledge between houses of Congress and among committees and members in each house.

Congress has created few joint committees, and some of them are concerned with administrative issues (e.g., government printing). Congress has, however, established two substantive committees, 
both on economic issues, which serve as our model: the Joint Economic Committee [25] and the Joint Committee on Taxation [26].

The Joint Economic Committee, created in 1946, reflects the pervasiveness and complexity of economic issues in federal legislation; its mission is to engage in continuing study of matters related to the economy. The Committee includes ten members each from the Senate and House of Representatives, allocated according to the partisan division in each house. Relying in large part on its expert staff, it conducts hearings, performs research and advises members of Congress. The Joint Committee on Taxation (JCT) is in some ways less apt as a model because of the technical nature of certain of its duties. For example, the Committee reviews especially large tax refunds to ensure that provisions of the law are working as intended. However, the non-partisan structure of the JCT and its leading role in the legislative process are important precedents for a Joint Committee on Sustainability. Accordingly, we focus primarily on this committee.

The JCT was created under the Revenue Act of 1926 [27], building on an earlier Senate Select Committee that investigated mismanagement in the Internal Revenue Service. The JCT includes five members each from the Senate and House, drawn from the main tax-writing committees: Senate Finance and House Ways and Means. The majority in each house appoints three members, the minority two. The Chairs of Senate Finance and House Ways and Means alternate chairing the JCT. The Committee appoints a Chief of Staff, who is responsible for selecting the remainder of the staff on a non-partisan basis.

The broad statutory duties assigned to the Committee in 1926 - in essence, to study the tax system on an ongoing basis and make recommendations to the tax-writing committees-remain largely unchanged. In addition, the Budget Act of 1974 required the JCT to provide revenue estimates for proposed tax legislation; in this regard it complements the Congressional Budget Office, which estimates expenditures. In practice, however, the Committee's role has expanded far beyond these basic mandates; in particular, its staff has become a central actor in the tax legislative process.

The JCT staff advises members and their staff on the development and analysis of legislative proposals and the drafting of bills; supports committee hearings by preparing legal and economic analyses of issues and proposals and by drafting committee reports; participates in legislative markup sessions, helping to draft amendments and preparing committee explanations; advises members during floor debate; assists the representatives of both houses during conference and helps to craft compromises; and prepares final conference reports. In addition, throughout the process the staff responds to inquiries from members, consults with the Treasury Department and the Internal Revenue Service (IRS) on executive proposals and implementation issues, and meets with groups potentially affected by legislation. The Committee also works with the Executive branch and the Senate Foreign Relations Committee on tax-related treaties, and monitors Treasury/IRS positions to ensure they are consistent with Congressional intent.

The JCT attributes the expansion of its role, and the trust placed in it by members of Congress, to four structural features. The Committee's jointness provides continuity throughout the bicameral legislative process, ensuring that proposals are evaluated consistently at different stages of the process and obviating the need for any member, committee or house to repeat the work of other bodies. Its non-partisan character allows its staff to provide objective advice to members from both sides of the aisle and both houses, and to consider all facets of tax policy. Its specialization in tax affairs allows its 
staff to accumulate expertise in legal matters, economic analysis, revenue estimates and forecasts of taxpayer behavior. And its independence as a source of expertise helps Congress maintain independence from the Executive branch in tax matters.

A Joint Committee on Sustainability could be created with similar features and mandates. Structurally, such a Committee might be larger than the JCT, perhaps as large as the Joint Economic Committee, as its members would be drawn from a range of relevant subject-matter committees. Committee staff could be selected on a non-partisan basis and with interdisciplinary expertise, so that they could examine the scientific, social and legal aspects of sustainability. The JCT's broadest duty - to study the relevant laws ex post and recommend reforms-would be equally valuable in the sustainability context; like the Sustainability Law Reform Commission discussed below, the Committee could identify and address both gaps in the law that result in insufficient legal authority for sustainability policies, as well as existing provisions in the law that create positive impediments to sustainability. Ex ante, the Committee would provide continuity to the legislative process, facilitating the complex enactments needed for sustainability reform. The Committee could also provide input into Senate consideration of treaties, and would be a natural focal point for Congressional oversight of the implementation of sustainability legislation by the Executive. The JCT's revenue estimate function might be replaced by a mandate to review and summarize the scientific literature relevant to legislative proposals on an independent and non-partisan basis. As with the JCT, all of these functions would draw on the Committee's jointness, non-partisan character, specialization and independence.

\subsection{A Sustainability Law Reform Commission}

A Sustainability Law Reform Commission (SLRC) would be an independent body with legal as well as substantive expertise, preferably established by statute on a long-term or permanent basis. It would be tasked with reviewing existing federal law from the perspective of sustainability and recommending amendments, enactments and repeals; it would thus have an explicit ex post perspective. Traditional law reform commissions focus primarily on statutory law, which might also be the core mandate of the SLRC. Given the complexity of modern governance, however, it might be wise to extend this mandate to the review of regulations, or even judge-made law. In each case, the SLRC could identify and address both gaps in the law and provisions that create impediments to sustainability. Like all law reform commissions, the SLRC would be an advisory body; its recommendations would have legal force only if implemented by Congress or other authorities. Even without formal implementation, however, SLRC reports and recommendations might have significant subjective effects, e.g., by contributing to attitudinal changes within federal agencies and the broader public.

In the US, the leading law reform institutions are the National Conference of Commissioners on Uniform State Laws and the American Law Institute; in addition, several states have active law reform commissions [28,29]. The commission approach has been most widely adopted, however, in the countries of the Commonwealth: the UK and its devolved administrations; Canada and several of its provinces; Australia and several of its states; Hong Kong; Ireland; New Zealand and other jurisdictions. We use the Commonwealth approach as our model.

The first Commonwealth law reform agencies were created in the 1930s [30], but modern law reform commissions are largely a product of the 1960s and 1970s, beginning with the British Law 
Commissions in 1965 [31,32]. The modern law reform movement in particular reflects skepticism that legislatures, courts and other legal institutions- "overwhelmed by the seemingly unstoppable and uncontrollable wave of changes affecting society" - can keep an expanding corpus of law up to date or respond to all of society's needs for legal rules ([31], p. 8).

Modern commissions reflect the idea that "the whole body of the law [stands] potentially in need of reform, and there should be a standing body of appropriate professional experts to consider reforms continuously" [33]. Accordingly, most are permanent expert bodies with a modest number of full-time commissioners and a substantial research staff, broad mandates and systematic working methods, funded (at least until recently) largely by government [34]. A crucial feature is a substantial degree of independence from government, parties and other political actors (as well as from interest groups, including the legal profession) [35]. Commission independence is enhanced by statutory authority, but also requires government forbearance on appointments, terms of reference and budgeting. Commissions are simultaneously accountable to the public through reporting and often through government approval of their work agendas [36,37].

One potential difficulty in adapting the law reform commission model to sustainability is that traditional commissions are generalist, charged with reviewing "the whole body of the law" for any problems requiring reform, whereas the SLRC would be concerned only with issues relevant to sustainability. In fact, however, because sustainability cuts across virtually every area of law, the SLRC would have a similarly broad field of action, albeit from a single substantive perspective. Indeed, the ability of the SLRC to review the whole legal corpus would be one of its major virtues.

A second problem of adaptation is that law reform commissions have traditionally focused on relatively technical issues of black-letter law and on increasing legal efficiency through simplification, codification, harmonization and procedural improvements. As a result, many jurisdictions require that commissioners be lawyers [31]. Legal competence would of course be a central requirement for the SLRC, as its core mission would be to review complex bodies of law and propose appropriate modifications. However, a technical legal approach would be inappropriate. The SLRC would also require policy expertise in multiple disciplines relevant to sustainability to identify areas where reform is needed. Fortunately, there exist both rationales and precedents for a more policy-oriented approach and structure.

Many experienced observers argue that even traditional commissions should move beyond legal efficiency by addressing complex emerging issues and taking account of social context and political currents ([31], p. 41). Some argue more aggressively that commissions should be "agents of change. They may ... be at the forefront of legal development ... identifying areas where there is a need for new law, in reviewing areas of law which are being affected by new features of life and in recommending imaginative new legislation. Examples of such fields of law are: environmental law; globalisation; ... human rights; ... rights of indigenous people; ... poverty; and ethics"-all relevant to sustainable development ([36], p. 7).

In practice, moreover, law reform commissions already deal with issues that are complex, contentious and value-laden - even though few of those issues are as sweeping and multi-faceted as sustainability. Examples include security and anti-terrorism legislation, corruption and transformative justice, tissue transplants, privacy, and the customary law of indigenous peoples ([35], p. 3; [37], p. 31). The policy perspective has also influenced institutional structure. Some commissions now include 
non-lawyers, accept proposals for work and other input from multi-stakeholder advisory councils or members of the public, and forge partnerships with interested groups. Others use consultants and external working parties to gain broader expertise and perspectives. Some are required to pursue an interdisciplinary approach, necessitating expanded consultation and participation. And most consult broadly with stakeholders and where necessary the public at large, as well as publicly reporting on their work [31,36,37].

Nonetheless, it is difficult to assess how effective an SLRC would be faced with a task as challenging as enhancing the sustainability of U.S. law. The threshold issue is the appropriate measure of "effectiveness". One obviously important measure would be the passage of legislation prompted by commission recommendations. Some law reform commissions report remarkably high rates of legislative response, upwards of 2/3 (the rate for the Law Commission for England and Wales) [36]; however, these figures are likely increased by the technical, efficiency-focused nature of the commissions' work; promoting sustainability would be far more controversial. Still, the South African Law Reform Commission, which has dealt with unusually sensitive issues as part of "the fundamental transformation of the country into one that is non-racial and non-sexist", has a response rate near $50 \%$ ([36], pp. 8,10).

Law reform experts are quick to note, however, that legislative response should not be the only measure of effectiveness, given the vagaries of law-making. Commission recommendations often influence public and official attitudes, producing legal change over time and through multiple channels, including judicial rulings as well as legislation ([36], pp. 9-10). An SLRC, moreover, could be authorized to address recommendations to administrative agencies as well as Congress, opening another avenue for legal action. In all these settings, an SLRC could play an extremely valuable role as agenda-setter, "identifying areas where there is a need for new law ... [and] reviewing areas of law which are being affected by new features of life", even if it did not propose specific legislative responses.

In sum, as Murphy notes based on the Canadian experience: "The law must be stable, yet it cannot be static. The challenge is to ensure that the legal system remains responsive to society's changing needs. One of the most effective ways to bring about legal change is arguably the specialized law reform agency" ([31], p. 1).

\subsection{A Sustainability Commission}

A Sustainability Commission would be an advisory body tasked and staffed to address a wide range of sustainability issues and thus an equally wide range of government agencies. Ex ante, the Commission could advocate and help executive departments and independent agencies develop appropriate sustainability policies, programs and regulations, addressing both government's own operations (from procurement to the management of public lands) and society at large. It could likewise advise Congress on new sustainability legislation. Ex post, the Commission could potentially be authorized to review existing statutes, regulations and programs from a sustainability perspective and to recommend modifications, although that would require a significant degree of legal expertise. (The Sustainability Law Reform Commission discussed in the previous subsection would have a more appropriate structure for this function.) In addition, as individual agencies or the government as a 
whole adopt sustainability targets and strategies the Commission could monitor progress in meeting them, while promoting more effective implementation through advice and capacity-building. Finally, the Commission could educate the public on the demands of sustainability and help build public support for appropriate action.

Our model is the United Kingdom Sustainable Development Commission (SDC) [38]. SDC was created in 2000, charged with acting as independent advisor and "critical friend" to the national government on sustainable development issues. As SDC broadened its influence, the government strengthened its formal role and institutional structure. The 2005 UK sustainable development strategy, "Securing the Future", gave SDC a mandate to act as a "watchdog for sustainable development", rather than merely a "critical friend" [39]. Beginning in 2006, the government provided additional resources to support SDC's expanded monitoring. In 2009, SDC became an independent legal entity.

SDC is led by a board of Commissioners, drawn from academia, business, science and civil society, and appointed by the Prime Minister for 3-year terms. Each Commissioner is assigned a specific portfolio, either substantive (e.g., climate change and energy, sustainable consumption) or institutional (e.g., Whitehall, the devolved administrations of Scotland, Wales and Northern Ireland). The Commission is supported by a secretariat, originally housed in the Department of Environment, Food and Rural Affairs (Defra), but independent since 2009. SDC has created a virtual Sustainable Development Panel of stakeholders which it consults on a range of issues. The bulk of its financial support comes from Defra and other government ministries, but SDC has also received some support from non-governmental sources, including WWF-UK.

SDC sees itself as playing four major roles, all transferable to the U.S. context. First, it advises government, drawing on outside experts and its own personnel to formulate input into national policies. While its principal relationships are with ministries, it also works directly with Parliament, providing advice on legislative and oversight activities. In addition, SDC contributes to public debate by releasing analytical reports on controversial issues. Second, it advocates sustainable development, building awareness of sustainability issues within government and the public and working toward agreement on effective responses. Since its formation, SDC has argued that sustainable development must become "the central organising principle underpinning our society" [40]. Third, it builds capacity, working to develop a deeper understanding of sustainable development among public officials and identifying and sharing good practices across agencies and levels of government. Fourth, in its "watchdog" role it monitors government. SDC regularly reviews and issues public assessments of the sustainability of public policies and governmental operations, such as procurement and general administration, including carbon emissions, waste and energy use. SDC cooperates with the House of Commons Environmental Audit Committee and the National Audit Office to enhance monitoring.

The UK political context renders SDC's monitoring activities unusually concrete. As noted above, the government has adopted a comprehensive sustainable development strategy; while the strategy is built on broad principles - such as living within environmental limits and promoting participatory governance - it is backed by 68 specific indicators, from greenhouse gas emissions to housing density to child poverty. In addition, the government requires all departments and agencies to adopt Sustainable Development Action Plans and issue annual progress reports. SDC helps departments to prepare their plans, uses the plans to promote sustainable development among department staff, and monitors departments' progress in meeting them. This extensive planning and reporting process adds 
focus to SDC's work and enhances its political leverage. The U.S. lacks a national sustainability strategy, let alone concrete indicators and agency action plans. The absence of these elements would undoubtedly impede (but would not obviate) a Sustainability Commission's monitoring function. However, their absence only enhances the importance of the Commission's advocacy, advisory and capacity-building missions. Beyond merely advocating and advising on specific legislation, regulations and policies, moreover, a Commission could frame its positions within a broader context, helping to promote the development of a comprehensive strategy. Indeed, a Sustainability Commission would be a natural focal point for actually coordinating the development of a national strategy.

In the U.S., governmental advisory commissions are common, although few are permanent bodies. A Sustainability Commission modeled on SDC might thus be broadly acceptable to executive officials and legislators, at least in principle. Indeed, the Clinton Administration created a President's Council on Sustainable Development, which (unlike SDC) included a number of high executive officials [41]. Compared to some other institutions discussed here, moreover, a commission similar to SDC would have little mandatory authority, and might be more acceptable for that reason. The question, though, is whether it would still have any meaningful impact. A wide-ranging critique of the UK experience, published in October 2009 by the initial Chair of SDC, Jonathon Porritt, provides important lessons [42].

Porritt views the UK's sustainable development architecture as innovative and well-designed, and identifies significant successes: SDC has worked with sympathetic officials to promote sustainable development across government; pioneered innovative approaches, such as the self-appraisal system now used throughout the National Health Service; helped departments develop action plans, monitored their implementation and created pressure for compliance; and built public interest and support for sustainable development [42]. Many of the same benefits could be expected in the U.S.

Overall, however, Porritt finds that the UK system has failed to produce the desired sustainability outcomes [42]. He attributes this failure primarily to subjective factors, notably a continuing societal commitment to economic growth and the absence of an alternative sustainable economic model; and an understanding of sustainable development as purely environmental, rather than as also economic and social, limiting its political salience. Institutional barriers have also limited progress: these include the difficulty of overcoming established departmental "silos" and creating an ethos of horizontal or cooperative governance; the reluctance of certain powerful departments to participate; and the vulnerability of broad goals like sustainable development to the "churn" of immediate issues and initiatives. Both sets of obstacles would hamper any sustainable development institution in the US, but would be especially daunting for an advisory body like SDC. Porritt's critique suggests that a Sustainability Commission could only overcome them with strong support at the highest political levels.

\section{Comparing the Mechanisms}

The five mechanisms we have discussed vary substantially on multiple dimensions, including institutional structure, function, authority and type of law and policy addressed. Here we highlight two particularly significant variations, not purely as an exercise in typology, but to prompt consideration of additional complementary mechanisms. 
First, the five mechanisms have different degrees of legal authority, from relatively "hard" to quite "soft" [43]. This paper has presented the mechanisms in roughly descending order of legal authority, as shown below.

Table 1. Legal authority.

\begin{tabular}{|c|c|l|}
\hline \multirow{4}{*}{ Hard } & Mechanism & \multicolumn{1}{c|}{ Explanation } \\
\cline { 2 - 3 } & Executive Order & $\begin{array}{l}\text { Mandatory for agencies; mandates may be vague; } \\
\text { no external enforcement }\end{array}$ \\
\cline { 2 - 3 } & EIA & $\begin{array}{l}\text { Mandatory for agencies; only requires "assessment;" } \\
\text { enforceable }\end{array}$ \\
\cline { 2 - 3 } & Joint Committee & Structures legislative process; does not control it \\
\cline { 2 - 3 } Soft & Law Reform & Advisory only \\
\cline { 2 - 3 } & Commission & Advisory only; modest oversight function \\
\hline
\end{tabular}

The two mechanisms at the top of the list are legally binding on regulatory agencies and may include precise mandates, such as meeting green building standards. In addressing broad goals like sustainability, however, even they tend to require relatively soft actions, such as "assessment". This weakness may be inherent in the nature of the issue, at least until more precise criteria are developed. In the middle of the list, a joint committee can facilitate and improve sustainability legislation, but cannot guarantee its passage. The final two mechanisms are purely advisory, although they may have significant indirect effects.

Two conclusions follow from this analysis: one should have realistic expectations for what any mechanism can accomplish in a field as complex and controversial as sustainability, and further research should seek both to enhance the mechanisms presented here and to identify more effective alternatives. Scholars have already identified some potentially valuable mechanisms-e.g., revising the Government Performance and Results Act to expressly include sustainability metrics against which agencies must annually evaluate their performance [44] — and models - e.g., the national environmental courts established in India [45] and Canada's Commissioner of the Environment and Sustainable Development, created to monitor agency progress in implementing sustainable development ([44], pp. 107-108). In considering other options, Table 1 makes clear that institutions with widely varying forms and levels of legal authority can make valuable contributions to sustainability law and policy; consideration should not be limited to institutions with "hard" legal mandates.

Second, the five mechanisms presented here address different forms of law and policy, and do so in different temporal perspectives, as shown below in Table 2. In this Table, we indicate an institution's major focus in all capitals, a minor focus in lower case. 
Table 2. Focus of institutions.

\begin{tabular}{|c|c|c|}
\hline & Ex Post & Ex Ante \\
\hline Statutes & $\begin{array}{c}\text { LAW REFORM } \\
\text { Joint Committee }\end{array}$ & JOINT COMMITTEE \\
\hline Regulations & $\begin{array}{c}\text { Executive Order } \\
\text { Law Reform }\end{array}$ & $\begin{array}{c}\text { EXECUTIVE ORDER } \\
\text { Impact Assessment } \\
\text { Commission }\end{array}$ \\
\hline Policies, Programs & Commission & $\begin{array}{c}\text { IMPACT ASSESSMENT } \\
\text { COMMISSION }\end{array}$ \\
\hline
\end{tabular}

As Table 2 makes clear, the five mechanisms cover all major forms of government action other than judicial rulings: legislation, administrative regulations, policies, programs and projects. What is more, they operate both prospectively (ex ante)-influencing consideration of new statutes, regulations and programs - and retrospectively (ex post) - influencing the review of existing measures. They are, however, somewhat unbalanced: only one mechanism (the Sustainability Law Reform Commission) is designed to focus primarily on existing law; and the majority of the mechanisms address executive rather than legislative action. These imbalances suggest priority areas for future research.

\section{Conclusions}

To implement sustainability effectively across the federal government and legal system will require significant institutional change. We have described five potential institutional mechanisms designed to advance sustainability on a horizontal, integrated basis. All five represent either modest extensions of existing U.S. institutions or adaptations of institutions operating in other jurisdictions. As such, all are potentially achievable innovations. While we do not necessarily recommend adoption of all five proposals, implementing two or more simultaneously could create valuable synergies.

As Table 2 suggests, for example, it should be fruitful, and should minimize institutional rivalry and conflict, to combine mechanisms focused on different forms of action, such as a joint Congressional committee on sustainability and an E.O. governing adoption of regulations. The same might be true of combining predominantly ex ante and ex post mechanisms, such as a law reform commission plus a joint committee, E.O. or impact assessment process. Table 1 suggests, moreover, that hard and soft mechanisms could be complementary; for example, a Sustainability Commission could be established to advocate for sustainability and provide advice on regulations and programs, while a review program for actual regulatory proposals could be initiated under an E.O. In some cases it may be possible to combine multiple mechanisms within a single organization, e.g., providing a Sustainability Commission with sufficient legal expertise to also operate as a Sustainability Law Reform Commission. Additional options are almost certainly available.

Institutions alone are insufficient, however; one must also define and operationalize sustainability principles in terms of strategies, priorities, practical legal rules and indicators. All of the mechanisms we have discussed are designed to apply sustainability principles, in different ways-e.g., by assessing proposed policies or projects against established criteria and priorities, or by monitoring improvements in performance according to established indicators. To the extent the underlying principles remain 
poorly defined or ad hoc, the effectiveness of the institutions will be compromised. Thus, institutional reform and substantive norm development must proceed hand-in-hand.

An important first step would be the adoption by the U.S. of a sustainable development strategy, as called for by multiple international declarations since Agenda 21 in 1992 [46]. Currently, the US is one of a limited number of developed countries that lack any meaningful strategy [47-49]. A successful strategy would set national objectives and priorities, operationalize sustainability principles, establish institutions and policy initiatives, and initiate an iterative learning process. ([48], pp. 153-154; [50]). In addition, developing the strategy would be valuable in itself: governments have used consultations with stakeholders and agencies to promote sustainability, establish collaborative networks, and develop buy-in from interested parties [51]. With such a base to work from, the mechanisms we have discussed could make important contributions to institutionalizing sustainability across the government and legal system.

\section{Acknowledgment}

Funding for research and drafting of this article was provided by the Institute for Humanities Research at Arizona State University.

\section{References and Notes}

1. World Commission on Environment and Development. Our Common Future (Bruntland Commission Report); United Nations: New York, NY, USA, 1987.

2. Dernbach, J.C. Navigating the U.S. transition to sustainability: Matching national governance challenges with appropriate legal tools. Tulsa Law Rev. 2008, 44, 93-119.

3. Craig, R.K.; Ruhl, J.B. Governing for sustainable coasts: Complexity, climate change, and coastal ecosystem protection. Sustainability 2010, 2, 1361-1388.

4. Adger, W.N.; Jordan, A. Sustainability: Exploring the processes and outcomes of governance. In Governing Sustainability; Adger, W.N., Jordan, A., Eds.; Cambridge University Press: Cambridge, MA, USA, 2009; p. 3.

5. Gaziano, T.F. The use and abuse of executive orders and other presidential directives. Tex Rev. Law Polit. 2001, 5, 267-316.

6. White House. Executive Order 12898-Federal Actions to Address Environmental Justice in Minority Populations and Low-Income Populations. Fed. Regist. 1994, 79, 7629-7634.

7. Franzen, A.K. The time is now for environmental justice: Congress must take action by codifying Executive Order 12898. Penn. State Environ. Law Rev. 2009, 17, 379-406.

8. Binder, D.; Crawford, C.; Gauna, E.; Jarman, M.C.; Kaswan, A.; Mank, B.C.; O’Neill, C.A.; Rechtschaffen, C.; Verchick, R.R.M. A survey of federal agency response to President Clinton's Executive Order No. 12898 on environmental justice. Environ. Law Rep. 2001, 31, 11133-11167.

9. White House. Executive Order 13514-Federal leadership in environmental, energy, and economic performance. Fed. Regist. 2009, 74, 52117-52127.

10. Branum, T.L. President or King? The use and abuse of Executive Orders in modern-day America. J. Legis. 2002, 28, 1-86. 
11. See infra notes $38-42$ and accompanying text.

12. Executive Order No. 4: Establishing a state green procurement and agency sustainability program, 25 April 2008. New York State, Governor David A. Paterson; Available online: http://www. state.ny.us/governor/executive_orders/exeorders/eo_4.html (accessed on18 January 2010).

13. Rodgers, W.H. Executive Orders and Presidential Commands: Presidents riding to the rescue of the environment. J. Land Resour. Environ. Law 2001, 21, 13-24.

14. Schiffer, L.J. The national environmental policy act today, with an emphasis on its application across U.S. borders. Duke Environ. Law Policy Forum 2004, 14, 325-345. In addition, the EIA model has been adapted to require assessments of other types of effects; one prominent example is regulatory impact assessment. European Commission. 2009. "Impact Assessment"; Available online: http://ec.europa.eu/governance/better_regulation/impact_en.htm (accessed on 18 January 2010).

15. National Environmental Policy Act (1969), 42 U.S.C. $\S \S 4321-4375$ A, § 101(b).

16. Lindstrom, M.J. Procedures without Purpose: The withering away of the National Environmental Policy Act's Substantive Law. J. Land Resour. Environ. Law 2000, 20, 245-267.

17. Hodas, D.R. The role of law in defining sustainable development: NEPA reconsidered. Widener Law Symp. J. 1998, 3, 1-60.

18. 42 U.S.C. $\S 4332$ (2)(C)(iv) (emphasis added). We thank John Dernbach for this suggestion.

19. Karkkainen, B.C. Toward a smarter NEPA: Monitoring and managing government's environmental performance. Columbia Law Rev. 2002, 102, 903-972.

20. Noble, B.F. Promise and dismay: The state of strategic environmental assessment systems and practices in Canada. Environ. Impact Assess Rev. 2009, 29, 66-75.

21. Environment, Growth and Development, Development Committee Paper 14; World Bank: Washington, DC, USA, 1987.

22. Chaker, A.; El-Fadl, K.; Chamas, L.; Hatjian, B. A review of strategic environmental assessment in 12 selected countries. Environ. Impact Assess. Rev. 2006, 26, 15-56.

23. Noble, B.F. The Canadian experience with SEA and sustainability. Environ. Impact Assess. Rev. 2002, 22, 3-16.

24. Government of Canada. Strategic Environmental Assessment: The Cabinet Directive in the Environmental Assessment of Policy, Plan and Program Proposals: Guidelines for Implementing the Cabinet Directive; Privacy Council Office: Ottawa, Canada, 2004; Available online: http://www.ceaa.gc.ca/Content/B/3/1/B3186435-E3D0-4671-8F23-2042A82D3F8F/CEAAStrategicFinal_e.pdf (accessed on19 January 2010).

25. Committee Background; Joint Economic Committee: Washington, DC, USA, 2007; Available online: http://jec.senate.gov/index.cfm?FuseAction=About.Committee Background (accessed on 20 January 2010).

26. About Us; Joint Committee on Taxation: Washington, DC, USA, 2009; Available online: http://www.jct.gov/about-us/overview.html (accessed on 20 January 2010).

27. The Committee's authority is now incorporated in the Internal Revenue Code of 1986, 26 U.S.C. $\S \S 8001-8005,8021-8023$.

28. Law Reform Commissions Worldwide; University of Cambridge: Cambridge, UK, 2009; Available online: http://www.law.cam.ac.uk/resources_reform.php (accessed on 21 January 2010). 
29. Law Commissions; World Bank: Washington, DC, USA, 2009; Available online: http://web.worldbank.org/WBSITE/EXTERNAL/TOPICS/EXTLAWJUSTINST/0,,contentMDK: 20751346 menuPK:2035051 pagePK:210058 piPK:210062 theSitePK:1974062,00.html (accessed on 21 January 2010).

30. Some US agencies were created even earlier. The first meeting of state commissioners on uniform law took place in 1892; ALI was founded in 1923 to address legal uncertainty and complexity as well as lack of uniformity. New Jersey created its law reform commission in 1925.

31. Murphy, G. Law Reform Agencies; The International Cooperation Group, Department of Justice of Canada: Ontario, Canada, 2004; Available online: http://www.legislationline.org/ download/action/download/id/2047/file/Canada_LawReformAgencies_2004.pdf (accessed on 21 January 2010), discussing Canadian experience.

32. Tilbury, M. A history of law reform in Australia. In The Promise of Law Reform; Opeskin, B., Weisbrot, D., Eds.; The Federation Press: Sydney, Australia, 2005; pp. 3-17.

33. Sawer, G. The legal theory of law reform. Univ. Tor. Law Rev. 1970, 20, 183-195.

34. The rise of neoliberal thought in the 1980s led to skepticism about law reform and the abolition or downsizing of many commissions. Tilbury, supra note 32, pp. 15-17.

35. Murphy states: "The profession not only has vested interests, it also is often blind to the need for genuine and responsive change in society and the law..." Murphy, supra note 31, p. 49.

36. Commonwealth Secretariat. Background paper for meeting of commonwealth law ministers and senior officials, law reform agencies: Their role and effectiveness. $\operatorname{LMM}(05) 4$ (2005), pp. 3-4; Available online: http://www.calras.org/Other/future_commonwealth.htm (accessed on 21 January 2010).

37. Weisbrot, D. The future for institutional law reform. In The Promise of Law Reform; Opeskin, B., Weisbrot, D., Eds.; The Federation Press: Sydney, Australia, 2005; pp. 18-39, 27-29.

38. Further information on the Sustainable Development Commission is available on its website: http://www.sd-commission.org.uk/index.php (accessed on 21 January 2010). For a discussion of Commission governance arrangements, see Sustainable Development Commission, UK. Governance and Management in the SDC. 2007; Available online: http://www. sd-commission.org.uk/publications/downloads/Governance_and_Management.pdf (accessed on 21 January 2010).

39. HM Government. Securing the Future: The UK Government Sustainable Development Strategy; The Stationery Office: London, UK, 2005; Available online: http://www.defra.gov.uk/sustainable/ government/publications/uk-strategy/documents/SecFut_complete.pdf (accessed on 21 January 2010).

40. Sustainable Development Commission, UK. News release: Sustainable development commission launches annual review. 2001; Available online: http://www.sd-commission.org.uk/ publications/downloads/News\%20Release\%20003\%20-\%20Review.pdf (accessed on 21 January 2010).

41. Dernbach, J.C. Learning from the President's Council on sustainable development: The need for a real national strategy. Environ. Law Rep. 2002, 32, 10648-10666. Oregon has created a similar body, the Sustainability Board. Available online: http://sustainableoregon.net/oregon/ (accessed on 21 January 2010). 
42. Porritt, J. The Standing of Sustainable Development in Government; Forum for the Future: London, UK, 10 November 2009; Available online: http://www.forumforthefuture.org.uk/ blog/the-standing-of-sustainable-development-in-government (accessed on 21 January 2010).

43. Abbott, K.W.; Keohane, R.; Moravcsik, A.; Slaughter, A.M.; Snidal, D. The concept of legalization. Int. Organ. 2000, 54, 401-419.

44. Dernbach, J.C. Navigating the U.S. transition to sustainability: Matching national governance challenges with appropriate legal tools. Tulsa Law Rev. 2008, 44, 93-119.

45. Sharma, R. Green courts in India: Strengthening environmental governance? Law Environ. Dev. J. 2008, 4, 50-71.

46. Dalal-Clayton, B.; Bass, S. A Review of Monitoring Mechanisms for National Sustainable Development Strategies; International Institute for Environment and Development: London, UK, 2006; Environmental Planning Issues No. 27, p. 5.

47. Dernbach, J.C. Toward a National Sustainable Development Strategy. Buffalo Environ. Law J. 2002-2003, 10, 69-128.

48. Meadowcroft, J. National sustainable development strategies: Features, challenges and reflexivity. Eur. Environ. 2007, 17, 152-163.

49. Good Practices in the National Sustainable Development Strategies of OECD Countries; Organisation for Economic Co-Operation and Development (OECD): Paris, France, 2006; Available online: http://www.oecd.org/dataoecd/58/42/36655769.pdf (accessed on 21 January 2010).

50. Volkery, A.; Swanson, D.; Jacob, K.; Bregha, F.; Pinter, L. Coordination, challenges, and innovations in 19 national sustainable development strategies. World Dev. 2006, 34, 2047-2063.

51. Jones, B. Trying harder: Developing a new sustainable strategy for the UK. Nat. Resour. Forum 2006, 30, 124-135.

(C) 2010 by the authors; licensee MDPI, Basel, Switzerland. This article is an Open Access article distributed under the terms and conditions of the Creative Commons Attribution license (http://creativecommons.org/licenses/by/3.0/). 